\title{
Systematic review of randomized clinical trials on the use of hydroxyethyl starch for fluid management in sepsis Christian J Wiedermann
}

\author{
Address: Division of Internal Medicine 2, Department of Medicine, Central Hospital of Bolzano, Bolzano, Italy
}

Email: Christian J Wiedermann - christian.wiedermann@asbz.it

Published: 24 January 2008

BMC Emergency Medicine 2008, 8:I doi:10.1 186/147|-227X-8-I

This article is available from: http://www.biomedcentral.com/I47I-227X/8/I

C) 2008 Wiedermann; licensee BioMed Central Ltd.

This is an Open Access article distributed under the terms of the Creative Commons Attribution License (http://creativecommons.org/licenses/by/2.0), which permits unrestricted use, distribution, and reproduction in any medium, provided the original work is properly cited.
Received: 6 June 2006

Accepted: 24 January 2008

\begin{abstract}
Background: Patients with sepsis typically require large resuscitation volumes, but the optimal type of fluid remains unclear. The aim of this systematic review was to evaluate current evidence on the effectiveness and safety of hydroxyethyl starch for fluid management in sepsis.

Methods: Computer searches of MEDLINE, EMBASE and the Cochrane Library were performed using search terms that included hydroxyethyl starch; hetastarch; shock, septic; sepsis; randomized controlled trials; and random allocation. Additional methods were examination of reference lists and hand searching. Randomized clinical trials comparing hydroxyethyl starch with other fluids in patients with sepsis were selected. Data were extracted on numbers of patients randomized, specific indication, fluid regimen, follow-up, endpoints, hydroxyethyl starch volume infused and duration of administration, and major study findings.
\end{abstract}

Results: Twelve randomized trials involving a total of 1062 patients were included. Ten trials (83\%) were acute studies with observation periods of 5 days or less, most frequently assessing cardiorespiratory and hemodynamic variables. Two trials were designed as outcome studies with follow-up for 34 and 90 days, respectively. Hydroxyethyl starch increased the incidence of acute renal failure compared both with gelatin (odds ratio, 2.57; 95\% confidence interval, I.13-5.83) and crystalloid (odds ratio, I.8I; 95\% confidence interval, I.22-2.7I). In the largest and most recent trial a trend was observed toward increased overall mortality among hydroxyethyl starch recipients (odds ratio, I.35; 95\% confidence interval, 0.94-I.95), and mortality was higher ( $\mathrm{P}<$ $0.00 \mathrm{I}$ ) in patients receiving $>22 \mathrm{~mL} \cdot \mathrm{kg}^{-1}$ hydroxyethyl starch per day than lower doses.

Conclusion: Hydroxyethyl starch increases the risk of acute renal failure among patients with sepsis and may also reduce the probability of survival. While the evidence reviewed cannot necessarily be applied to other clinical indications, hydroxyethyl starch should be avoided in sepsis.

\section{Background}

Sepsis and its frequent accompaniments - septic shock, systemic inflammatory response syndrome (SIRS) and adult respiratory distress syndrome (ARDS) - are major causes of multiple organ failure and mortality in hospitalized patients [1]. Overall hospital mortality rates of 21-
47\% have been reported among sepsis patients [2-5]. Acute renal failure (ARF) is a frequent complication [6]. Release of lipopolysaccharide endotoxin from the bacterial cell wall is among the mechanisms believed to initiate the signs, symptoms and physiologic and biochemical abnormalities characteristic of septic shock. Maldistribu- 
tion of fluid in the microcirculation is typical of septic shock and results from endotoxin-induced endothelial damage. In severe sepsis, acute circulatory failure is often associated with hypovolemia and inadequate venous return, cardiac output and tissue nutrient flow [7]. Hypovolemia is a significant risk factor for mortality in sepsis [8], and these patients often require large volumes of resuscitation fluids [9]. Persistent vasodilation may also contribute to mortality among patients with sepsis [10]. Due to increased capillary permeability albumin efflux from plasma to the interstitium is increased three-fold in septic shock patients [11]. Septic patients frequently develop hypoproteinemia, which is significantly correlated with fluid retention and weight gain, development of ARDS and mortality [12].

Colloids are widely used as first-line treatment, in particular in Europe, usually in combination with crystalloids [13]. The artificial colloid hydroxyethyl starch (HES) has gained increasing acceptance for fluid management in a variety of indications. HES solutions differ according to their average molecular weight, molar substitution defined as the proportion of hydroxyethyl units substituted per glucose monomer, and substitution pattern as characterized by the ratio of substitution at the $\mathrm{C} 2$ and $\mathrm{C} 6$ positions on the glucose ring. More rapid clearance of HES molecules from plasma is observed after infusion of HES solutions with lower molar substitution, C2/C6 ratio and, to a smaller extent, molecular weight [14]. Impetus for the usage of HES has been generated by the higher unit acquisition cost of albumin [15]. Nevertheless, as previously reviewed [16], safety concerns about HES have been mounting. Some complications of HES are dose-related, and sepsis patients may require prolonged fluid administration typically with relatively high cumulative volumes. Consequently, the safety of HES in this indication needs to be appraised with particular care. The systematic review presented here is the first to assess randomized clinical trials of HES in sepsis.

\section{Methods}

Randomized clinical trials evaluating HES in sepsis were sought by computer searches of the MEDLINE and EMBASE bibliographic databases and the Cochrane Library. Search terms included: hydroxyethyl starch; hetastarch; shock, septic; sepsis; randomized controlled trials; and random allocation. Additionally, reference lists were examined and selected specialty journals searched by hand. Eligibility was not restricted on the basis of trial endpoints, type of HES solution, time period or language of publication. Both published and unpublished trials were eligible for inclusion.

From the trial reports data were extracted on numbers of patients randomized, specific indication, fluid regimen, follow-up and endpoints. Extracted data also included the daily and cumulative HES doses and the duration of HES administration. Close attention was paid to the investigators, time periods and trial data to avoid duplication in case the same trial was the subject of multiple reports and to ensure completeness of the included evidence in the event that multiple reports of the same trial contained partially non-overlapping data.

Major findings of the included trials were qualitatively summarized and tabulated. Due to heterogeneity in the control regimens, endpoints, length of follow-up and other trial design features a quantitative meta-analysis was not judged to be feasible.

Descriptive statistics included the median and interquartile range (IQR). Calculations were performed with $\mathrm{R}$ version 2.2.1 statistical software (The R Foundation for Statistical Computing, Vienna, Austria).

\section{Results}

\section{Included trials}

The selection process for randomized clinical trials is depicted in Fig. 1. Twelve trials with a total of 1062 patients were included [7,9,17-27]. None was unpublished. With 537 patients, the recent Efficacy of Volume Substitution and Insulin Therapy in Severe Sepsis (VISEP) trial accounted for approximately half the patients in the review [27]. Two included trials were described by Rackow and co-workers in the 1980s $[7,9]$ and 5 by Boldt et al. in the 1990s [17-22]. The remaining 5 trials conducted by various teams of investigators were reported since 2000 [23-27]. One trial in a mixed population of patients with either septic or non-septic shock was excluded because septic shock was absent in approximately one-third of the patients and study endpoint results for septic versus other forms of shock were reported only in aggregate form $[28,29]$. Another trial involving 27 patients with severe

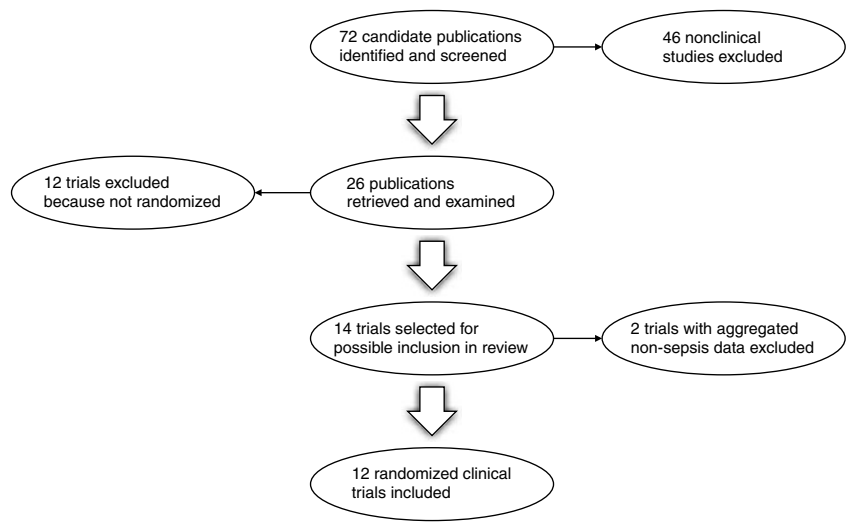

Figure I

Randomized trial selection process. 
sepsis and 36 with postoperative SIRS was also excluded due to aggregation of data [30]. Unaggregated data for that trial were requested from the investigators, but no response was received.

\section{Trial characteristics}

The characteristics of the included trials are summarized in Table 1. The median number of sepsis patients per trial was 30 (IQR, 26-64). Only three trials involved more than 100 patients $[22,24,27]$. Patients with severe sepsis or septic shock were enrolled in 6 trials $[7,9,24-27]$. Of the 6 other trials, 5 involved postoperative sepsis [17-22] and one sepsis with hypovolemia in ventilated and hemodynamically controlled patients [23].
HES with a molecular weight of $200 \mathrm{kDa}$ and molar substitution of 0.5 (HES 200/0.5) was evaluated in 8/12 trials $(67 \%)$. HES $200 / 0.62$ was investigated in two trials and HES 130/0.4 and HES 450/0.7 in one each. The control fluid was $20 \%$ albumin in 6 trials, gelatin in 3, 5\% albumin in 2 and crystalloid in one.

Ten trials (83\%) were acute studies in which the observation periods ranged from less than $1 \mathrm{~h}$ to a maximum of 5 days. Only two trials were designed as outcome studies with follow-up of 34-90 days.

Cardiorespiratory and hemodynamic variables were endpoints of 7 trials and coagulation parameters of 3. Other evaluated endpoints consisted of extravascular lung water,

Table I: Characteristics of included randomized trials

\begin{tabular}{|c|c|c|c|c|c|}
\hline Trial & $\mathbf{n}^{\dagger}$ & Indication & Fluid Regimen $\ddagger$ & Follow-Up & Endpoints \\
\hline Falk et al., I 988 [9] & 12 & Septic shock & $\begin{array}{l}6 \% \mathrm{HES} 450 / 0.7 \text { or } 5 \% \\
\text { albumin to } 15 \mathrm{~mm} \mathrm{Hg} \text { target } \\
\text { PAWP }\end{array}$ & $24 \mathrm{~h}$ & Coagulation \\
\hline Rackow et al., 1989 [7] & 20 & $\begin{array}{l}\text { Severe sepsis and } \\
\text { systemic } \\
\text { hypoperfusion }\end{array}$ & $\begin{array}{l}10 \% \text { HES } 200 / 0.5 \text { or } 5 \% \\
\text { albumin to } 15 \mathrm{~mm} \mathrm{Hg} \text { target } \\
\text { PAWP or } 2000 \mathrm{~mL} \text { maximum }\end{array}$ & $45 \mathrm{~min}$ & $\begin{array}{l}\text { Cardiorespiratory function } \\
\text { and coagulation }\end{array}$ \\
\hline Boldt et al., $1995[17,18]$ & 30 & $\begin{array}{l}\text { Sepsis after major } \\
\text { surgery }\end{array}$ & $\begin{array}{l}10 \% \text { HES } 200 / 0.5 \text { or } 20 \% \\
\text { albumin to } 12-16 \mathrm{~mm} \mathrm{Hg} \\
\text { target CVP, PCWP or both }\end{array}$ & 5 days & $\begin{array}{l}\text { Endothelial-related } \\
\text { coagulation and platelet } \\
\text { function }\end{array}$ \\
\hline Boldt et al., 1996 [19] & 30 & $\begin{array}{l}\text { Sepsis secondary to } \\
\text { major general surgery }\end{array}$ & $\begin{array}{l}10 \% \text { HES } 200 / 0.5 \text { or } 20 \% \\
\text { albumin to } 12-18 \mathrm{~mm} \mathrm{Hg} \\
\text { target PCWP }\end{array}$ & 5 days & $\begin{array}{l}\text { Cardiorespiratory and } \\
\text { circulatory variables }\end{array}$ \\
\hline Boldt et al., 1996 [20] & 42 & $\begin{array}{l}\text { Sepsis secondary to } \\
\text { major surgery }\end{array}$ & $\begin{array}{l}6 \% \text { HES } 200 / 0.5,20 \% \text { albumin } \\
\text { or pentoxifylline }\end{array}$ & 5 days & $\begin{array}{l}\text { Circulating soluble adhesion } \\
\text { molecules }\end{array}$ \\
\hline Boldt et al., I996 [2I] & 28 & $\begin{array}{l}\text { Sepsis secondary to } \\
\text { major surgery }\end{array}$ & $\begin{array}{l}10 \% \text { HES } 200 / 0.5 \text { or } 20 \% \\
\text { albumin to } 10-15 \mathrm{~mm} \mathrm{Hg} \\
\text { target PCWP }\end{array}$ & 5 days & Circulatory variables \\
\hline Boldt et al., 1998 [22] & 150 & Postoperative sepsis & $\begin{array}{l}10 \% \text { HES } 200 / 0.5 \text { or } 20 \% \\
\text { albumin to } 12-15 \mathrm{~mm} \mathrm{Hg} \\
\text { target PCWP }\end{array}$ & 5 days & $\begin{array}{l}\text { Hemodynamics, laboratory } \\
\text { data and organ function }\end{array}$ \\
\hline Asfar et al., 2000 [23] & 34 & $\begin{array}{l}\text { Sepsis and } \\
\text { hypovolemia in } \\
\text { ventilated and } \\
\text { hemodynamically } \\
\text { controlled patients }\end{array}$ & $\begin{array}{l}500 \mathrm{~mL} 6 \% \text { HES } 200 / 0.62 \text { or } \\
4 \% \text { succinylated modified fluid } \\
\text { gelatin }\end{array}$ & $60 \mathrm{~min}$ & $\begin{array}{l}\text { Hemodynamics and gastric } \\
\text { mucosal acidosis }\end{array}$ \\
\hline Schortgen et al., 200I [24] & 129 & $\begin{array}{l}\text { Severe sepsis or } \\
\text { septic shock }\end{array}$ & $\begin{array}{l}6 \% \mathrm{HES} 200 / 0.62 \text { up to } 4 \text { days } \\
\text { or } 80 \mathrm{~mL} \cdot \mathrm{kg}^{-1} \text { cumulative dose } \\
\text { or } 3 \% \text { gelatin }\end{array}$ & 34 days & ARF \\
\hline Molnár et al., 2004 [25] & 30 & $\begin{array}{l}\text { Septic shock with } \\
\text { hypovolemia and } \\
\text { acute lung injury }\end{array}$ & $\begin{array}{l}6 \% \text { HES } 200 / 0.5 \text { or } 4 \% \\
\text { modified fluid gelatin to } \\
\text { achieve ITBVI }>900 \mathrm{~mL} \cdot \mathrm{m}^{-2}\end{array}$ & $60 \mathrm{~min}$ & $\begin{array}{l}\text { Hemodynamics, EVLW and } \\
\text { oxygenation }\end{array}$ \\
\hline Palumbo et al., 2006 [26] & 20 & $\begin{array}{l}\text { Severe sepsis in } \\
\text { mechanically } \\
\text { ventilated patients }\end{array}$ & $\begin{array}{l}6 \% \mathrm{HES} 130 / 0.4 \text { or } 20 \% \\
\text { albumin to maintain PCWP of } \\
15-18 \mathrm{~mm} \mathrm{Hg}\end{array}$ & 5 days & $\begin{array}{l}\text { Hemodynamic and } \\
\text { oxygenation parameters }\end{array}$ \\
\hline Brunkhorst et al., 2008 [27] & 537 & $\begin{array}{l}\text { Severe sepsis or } \\
\text { septic shock }\end{array}$ & $\begin{array}{l}10 \% \text { HES } 200 / 0.5 \text { (to } 20 \\
\mathrm{~mL} \cdot \mathrm{kg}^{-1} \cdot \text { day }^{-1} \text { limit) or Ringer's } \\
\text { lactate to target of } \geq 8 \mathrm{~mm} \\
\mathrm{Hg} \mathrm{CVP}\end{array}$ & 90 days & Morbidity and mortality \\
\hline
\end{tabular}

Abbreviations: ARF, acute renal failure; CVP, central venous pressure; EVLW, extravascular lung water; HES, hydroxyethyl starch; ICU, intensive care unit; ITBVI, intrathoracic blood volume index; PAWP, pulmonary arterial wedge pressure; PCWP, pulmonary capillary wedge pressure tFor trials with more than one indication, includes only patients with sepsis.

†HES solutions specified by molecular weight/molar substitution. 
gastric mucosal acidosis, circulating soluble adhesion molecules, ARF and morbidity and mortality.

\section{HES posology}

Patients in the included trials received HES for a median of 5 days (IQR, $1-5$ days). The median daily HES dose was $12.6 \mathrm{~mL} \cdot \mathrm{kg}^{-1}\left(\mathrm{IQR}, 11.0-13.7 \mathrm{~mL} \cdot \mathrm{kg}^{-1}\right)$ and the median cumulative dose $49.8 \mathrm{~mL} \cdot \mathrm{kg}^{-1}\left(\mathrm{IQR}, 22.6-63.0 \mathrm{~mL} \cdot \mathrm{kg}^{-1}\right)$.

\section{Major findings}

Hemodynamic and cardiorespiratory variables were improved by HES 130/0.4 and HES 200/0.5 compared with $20 \%$ albumin $[19,22,26]$ but not gelatin [25]. Acute Physiology and Chronic Health Evaluation (APACHE) II score was also improved by HES 130/0.4 but not $20 \%$ albumin [26]. HES 200/0.5 either improved gastric intramucosal $\mathrm{pH}\left(\mathrm{pH}_{\mathrm{i}}\right)$ compared with $20 \%$ albumin [21] or avoided a decline in $\mathrm{pH}_{\mathrm{i}}$ observed in $20 \%$ albumin recipients [19]. On the other hand, gelatin raised $\mathrm{pH}_{\mathrm{i}}$ and decreased $\mathrm{CO}_{2}$ gastric mucosal arterial gradient, while HES 200/0.62 did not display these beneficial effects [23].

HES 450/0.7 impaired coagulation, as judged by prolonged partial thromboplastin time, and decreased platelet count [9]. These undesirable effects were not encountered in patients receiving 5\% albumin. HES 200/ 0.5 diminished factor VIII levels compared with 5\% albumin [7]. Differences in coagulation and platelet count between HES 200/0.5 and 20\% albumin were not observed in one trial [22]. Compared with crystalloid, HES 200/0.5 interfered with coagulation as indicated by a higher sequential organ failure assessment (SOFA) coagulation subscore $(\mathrm{p}<0.001)$ and greater median red blood cell transfusion requirement of 6 units (IQR, 4-12 units) vs. 4 units (IQR, 2-8 units) for the control group ( $\mathrm{p}<$ $0.001)[27]$.

In a trial of 129 patients with severe sepsis or septic shock by Schortgen et al. [24], the groups randomized to receive HES 200/0.62 or gelatin were similar at baseline in severity of illness and serum creatinine. However, over the 34 day study observation period the incidence of ARF was increased in the HES 200/0.62 recipients $(p=0.018)$. In a multivariate analysis with adjustment for fluid loading before inclusion and mechanical ventilation at inclusion, HES 200/0.62 exposure was shown to be an independent risk factor for ARF (Table 2). At the conclusion of the study, ARF incidence in the HES 200/0.62 group (61\%) exceeded that in the gelatin group (31\%) by $30 \%$ based on Kaplan-Meier analysis. The median time to ARF among patients receiving HES 200/0.62 was 16 days. An earlier trial by Boldt and co-workers [22] failed to detect an effect of HES 200/0.5 on incidence of renal failure, possibly as a result of the short 5 day observation period. In the trial of
Schortgen et al., a between-group difference in ARF incidence of only $11 \%$ was evident at the 5 day time point.

The recent multicenter VISEP trial assessing morbidity and mortality up to 90 days in 537 patients with severe sepsis or septic shock is the first large-scale outcome study of HES 200/0.5 in any clinical indication [27]. The HES 200/ 0.5 and crystalloid groups were well-matched at baseline in severity of illness and serum creatinine. HES 200/0.5 infusion compromised renal function $(\mathrm{p}=0.02)$ as reflected by a higher SOFA renal subscore than that of the control group. The incidence of ARF and use of renal replacement therapy (RRT) were both increased by HES 200/0.5 (Fig. 2). RRT usage was positively correlated with cumulative HES 200/0.5 dose ( $<<0.001)$. Even in the subset of patients receiving exclusively lower HES 200/0.5 doses $\left(\leq 22 \mathrm{~mL} \cdot \mathrm{kg}^{-1}\right)$, higher ARF incidence $(\mathrm{p}=0.04)$ and RRT utilization ( $\mathrm{p}=0.03$ ) were demonstrated in comparison with the crystalloid control group.

In the VISEP trial there was also an overall trend toward increased mortality among HES 200/0.5 recipients (Fig. 2). Mortality at 90 days was correlated with cumulative HES 200/0.5 dose $(p=0.001)$ and significantly increased ( $\mathrm{p}<0.001)$ in patients receiving $>22 \mathrm{~mL} \cdot \mathrm{kg}^{-1} \mathrm{HES} 200 /$ $0.5(58 \%)$ for at least one day than lower doses $(31 \%)$.

\section{Discussion}

Until relatively recently, randomized trial evidence concerning HES for fluid management in sepsis patients has stemmed almost entirely from small acute studies, often focused on cardiorespiratory and hemodynamic endpoints. These trials were thus not designed to evaluate safety or outcomes, and renal function in particular was not evaluated. The report of Schortgen et al. [24] was to first to raise serious concern that HES might adversely affect renal function in sepsis. The results of that trial should perhaps have been unsurprising in light of earlier randomized trials indicating deleterious effects of HES on the kidney in cardiac [31] and abdominal surgery [32] and renal transplantation [33]. The VISEP trial [27] has now furnished convincing confirmation that HES increases ARF incidence in sepsis.

The administration of HES 200/0.5 in the VISEP trial has also put to rest the argument that the adverse renal effects observed by Schortgen et al. might have been due to their use of the more highly substituted HES 200/0.62 solution. On the other hand it should be recognized that the results of sepsis trials involving repeated HES infusion over a period of several days or more cannot necessarily be extrapolated to other settings such as postoperative fluid management involving lower HES doses for a shorter time. 
Table 2: HES dose administered and major findings of included randomized trials

\begin{tabular}{|c|c|c|c|c|}
\hline \multirow[t]{2}{*}{ Trial } & \multirow[t]{2}{*}{ Days on HES } & \multicolumn{2}{|c|}{ Mean $\mathrm{mL} \cdot \mathrm{kg}^{-1}$ HES } & \multirow[t]{2}{*}{ Major Findings } \\
\hline & & Daily & Cumulative & \\
\hline Falk et al., 1988 [9] & 1 & $70.5 \dagger$ & $70.5^{\dagger}$ & $\begin{array}{l}\text { In HES } 450 / 0.7 \text { group PTT increased by } 20 \mathrm{~s}(\mathrm{p}=0.0 \mathrm{I}) \text { and platelet count } \\
\text { decreased by } 158 \times 10^{3} \mathrm{~mm}^{-3}(\mathrm{p}=0.0 \mathrm{I}) \text {; no significant PTT or platelet } \\
\text { count change in albumin group }\end{array}$ \\
\hline Rackow et al., 1989 [7] & 1 & $12.9 \dagger$ & $12.9 \dagger$ & $\begin{array}{l}\text { FVIII:c declined } 45 \% \text { in the HES } 200 / 0.5 \text { group compared with } 5 \% \text { in the } \\
\text { albumin group }(p=0.05)\end{array}$ \\
\hline Boldt et al., $1995[17,18]$ & 5 & 8.5 & 42.3 & $\begin{array}{l}\text { Plasma thrombomodulin increased in the albumin group and remained } \\
\text { unchanged in the HES } 200 / 0.5 \text { group }(p<0.05) \text {; plasma protein } C \text { among } \\
\text { HES } 200 / 0.5 \text { recipients increased on days } 4 \text { and } 5 \text { without corresponding } \\
\text { change in the albumin group }(p<0.05) \text {; maximum platelet aggregation } \\
\text { declined in both groups }(p<0.05)\end{array}$ \\
\hline Boldt et al., 1996 [19] & 5 & 11.0 & 55.2 & 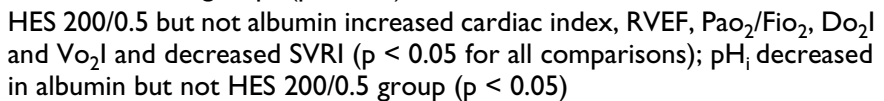 \\
\hline Boldt et al., 1996 [20] & 5 & 12.7 & 63.7 & $\begin{array}{l}\text { Circulating sELAM-I and sICAM-I concentrations reduced by HES } 200 / 0.5 \\
\text { compared with albumin ( } p<0.05 \text { for both comparisons) }\end{array}$ \\
\hline Boldt et al., 1996 [2I] & 5 & 11.0 & 49.8 & $\begin{array}{l}\text { Vasopressin, endothelin- } \mathrm{I} \text { and norepinephrine decreased and } \mathrm{pH}_{\mathrm{i}} \text { increased } \\
\text { in HES 200/0.5 but not albumin group }(\mathrm{p}<0.05 \text { for all comparisons); ANP } \\
\text { increased by albumin but not HES } 200 / 0.5(\mathrm{p}<0.05)\end{array}$ \\
\hline Boldt et al., 1998 [22] & 5 & 12.5 & 62.4 & $\begin{array}{l}\mathrm{PaO}_{2} / \mathrm{Fio}_{2}, \mathrm{Do}_{2} \mathrm{I} \text { and } \mathrm{Vo}_{2} \mathrm{I} \text { increased and lactate decreased by } \mathrm{HES} 200 / 0.5 \\
\text { but not albumin ( } \mathrm{P}<0.05 \text { for all comparisons); no differences in incidence } \\
\text { of renal failure, platelet count, } \mathrm{PT} \text { or aPTT }\end{array}$ \\
\hline Asfar et al., 2000 [23] & I & 7.9 & 7.9 & $\begin{array}{l}\text { Gelatin but not HES 200/0.62 increased } \mathrm{pH}_{\mathrm{i}}(\mathrm{p}<0.00 \mathrm{I}) \text { and decreased } \mathrm{CO}_{2} \\
\text { gastric mucosal arterial gradient }(\mathrm{p}<0.0005)\end{array}$ \\
\hline Schortgen et al., 200I [24] & $4 \ddagger$ & $14.0 \ddagger$ & $31.0 \ddagger$ & $\begin{array}{l}\text { HES 200/0.62 exposure an independent risk factor for ARF (adjusted odds } \\
\text { ratio, 2.57; Cl I.13-5.83) }\end{array}$ \\
\hline Molnár et al., 2004 [25] & I & $14.3^{\dagger}$ & $14.3^{\dagger}$ & No differences detected in ITBVI, EVLW or $\mathrm{PaO}_{2} / \mathrm{FiO}_{2}$ \\
\hline Palumbo et al., 2006 [26] & 5 & $--\S$ & $--\S$ & $\begin{array}{l}\text { Target PCWP of } 15-18 \mathrm{~mm} \mathrm{Hg} \text { maintained by both colloids; temperature, } \\
\text { MAP, PAP, CVP, heart rate and urine output remained stable without } \\
\text { differences between groups; } \mathrm{HES} 130 / 0.4 \text {, but not albumin, increased } \\
\text { cardiac index and several oxygenation parameters }\left(\mathrm{Pao}_{2} / \mathrm{Fio}_{2}, \mathrm{Do}_{2} \mathrm{I} \text { and }\right. \\
\left.\mathrm{Vo}_{2} \mathrm{I}\right) \text { and decreased APACHE II score }(\mathrm{P}<0.05 \text { for all within-group } \\
\text { comparisons) }\end{array}$ \\
\hline Brunkhorst et al., 2008 [27] & 21 & $--\S$ & $70.4 \pi$ & $\begin{array}{l}\text { Greater ARF incidence in HES } 200 / 0.5 \text { group (odds ratio, I.8I; } \mathrm{Cl}, \mathrm{I} .22- \\
2.7 \mathrm{I} ; \mathrm{p}=0.002 \text { ); increased mortality at higher HES } 200 / 0.5 \text { doses (odds } \\
\text { ratio, } 3.08 ; \mathrm{Cl}, \mathrm{I} .78-5.37 ; \mathrm{p}<0.00 \mathrm{I} \text { ) }\end{array}$ \\
\hline
\end{tabular}

Abbreviations: ANP, atrial natriuretic peptide; APACHE, Acute Physiology and Chronic Health Evaluation; aPTT, activated partial thromboplastin time; ARF, acute renal failure; $\mathrm{Cl}, 95 \%$ confidence interval; CVP, central venous pressure; $\mathrm{Do}_{2} \mathrm{l}$, oxygen delivery index; $\mathrm{EVLW}$, extravascular lung water; HES, hydroxyethyl starch; FVIII:c, factor VIII coagulant activity; ITBVI, intrathoracic blood volume index; MAP, mean arterial pressure; Pao ${ }_{2}$ / $\mathrm{FiO}_{2}$, ratio of partial pressure of arterial oxygen to fraction of inspired oxygen; PAP, pulmonary artery pressure; PCWP, pulmonary capillary wedge pressure; $\mathrm{pH}_{\mathrm{i}}$, gastric intramucosal $\mathrm{pH}$; $\mathrm{PT}$, prothrombin time; $\mathrm{PTT}$, partial thromboplastin time; $\mathrm{RVEF}$, right ventricular ejection fraction; sELAM-I, soluble endothelial leucocyte adhesion molecule-I; sICAM-I, soluble intercellular adhesion molecule-I; SVRI, systemic vascular resistance index; $\mathrm{Vo}_{2}$ l, oxygen consumption index

tCalculated from reported volume administered assuming $70 \mathrm{~kg}$ body weight.

¥Actual days on HES not specified. Maximum of 4 days imposed after start of study, and percentage of patients receiving HES longer not indicated.

Daily dose stated for day I only. Cumulative dose reported as median.

$\S$ Not reported.

IMedian.

The VISEP trial has also provided the first evidence that HES may increase mortality among sepsis patients. A trend toward higher mortality was observed among all recipients of HES compared with crystalloid, and mortality was significantly increased by higher HES doses. These data are in contrast to the results of the SAFE trial [34] comparing $4 \%$ albumin with normal saline. In the subset of 1218 SAFE trial patients with severe sepsis, a trend toward reduced mortality was evident in the albumin group (odds ratio, $0.81 ; 95 \%$ confidence interval, $0.63-$
1.04; $\mathrm{p}=0.09$ ). In light of these disparate survival trends, a need exists for an adequately powered outcome trial directly comparing HES and albumin in sepsis.

Schortgen et al. detected no effect of HES 200/0.62 on survival; however, the duration of follow-up in their trial was 34 days. In the VISEP trial the Kaplan-Meier survival curves for the two randomized groups began to diverge only at approximately 30 days and were clearly separated thereafter. It is thus possible that in the trial of Schortgen 


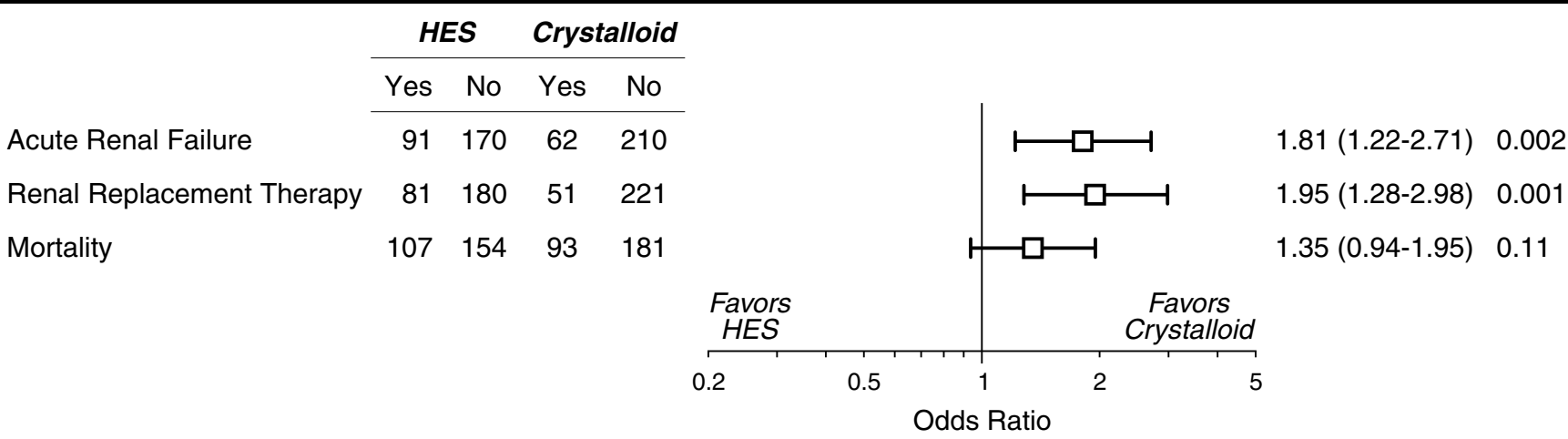

\section{Figure 2}

Incidence of acute renal failure, use of renal replacement therapy and mortality in patients receiving HES or crystalloid. Abbreviations: $\mathrm{Cl}, 95 \%$ confidence interval; HES, hydroxyethyl starch. Based on the data of Brunkhorst et al. [27].

et al. a mortality difference might have become apparent with longer follow-up.

The mechanisms that might account for undesirable HES effects on kidney function and possibly survival in sepsis are not understood. One putative mechanism is renal ischemia [24]. HES has been shown to increase plasma viscosity in vitro compared with albumin [35]. In a rat model of severe hemorrhagic shock, both 6\% HES and $5 \%$ albumin restored macrocirculatory function as measured by mean arterial pressure [36]. However, only albumin completely returned mesenteric microcirculatory blood flow to the baseline level. Furthermore, albumin was effective in restoring mesenteric lymphatic output, while HES was not $(\mathrm{p}<0.05)$.

Since more than 30 years ago there has been evidence that HES might impair reticuloendothelial system (RES) function, thereby impairing host defenses against sepsis and possibly contributing to multiple organ failure, including ARF, and mortality [37]. A substantial proportion of administered HES cannot be metabolized acutely and undergoes uptake and storage by the RES, most notably in macrophages including those localized in the kidney [3842]. In a quantitative necropsy specimen study of 12 young adult patients who had died due to sepsis and multi-organ failure after receiving a mean of $258 \mathrm{~mL} \cdot \mathrm{day}^{-}$ ${ }^{1}$ HES 200/0.5, the highest mean major organ HES tissue concentration was measured in the kidney $\left(13.7 \mathrm{mg} \cdot \mathrm{g}^{-1}\right)$ [43]. The effects of plasma substitutes on RES function in mice were investigated by intraperitoneal injection of Salmonella enteritidis endotoxin [37]. Host defenses against this endotoxin are mediated by RES macrophages. Prior infusion of HES but not plasma increased the lethality of endotoxin injected either $1 \mathrm{~h}(\mathrm{p}<0.05)$ or $3 \mathrm{~h}(\mathrm{p}<0.01)$ subsequently. Similarly, in a murine hemorrhagic shock model no HES-resuscitated animal survived intraperitoneal injection of live $E$. coli at $1 \mathrm{~h}$ after resuscitation, whereas survival with shed blood resuscitation was $64 \%$ [44]. In contrast to these two studies involving acute septic challenge within 1-3 $\mathrm{h}$ after HES administration, a delayed challenge in the form of cecal ligation and puncture $48 \mathrm{~h}$ after HES infusion did not increase mortality in rats [45]. In any case, there is at present no clinical evidence indicating HES-mediated impairment of RES function in sepsis, and clinical studies will be required to delineate the role, if any, of the RES in explaining the observed deleterious effects of HES among septic patients.

A variety of HES solutions are available that differ in average molecular weight, molar substitution, C2/C6 ratio and solvent. It has often been claimed that a particular HES solution may be devoid of safety problems displayed by others. Several recent evidence-based reviews have challenged this contention [16,46-48]. Similar types of complications, including impaired kidney function [48], have been encountered clinically across the entire spectrum of HES solutions. These adverse effects appear to reflect the intrinsic pharmacologic properties of the HES molecule rather than differences between individual HES solutions [49]. For instance, HES 130/0.4 was shown to impair renal function assessed by four sensitive markers in a randomized trial of elderly cardiac surgery patients [50]. HES 450/0.7 in Ringer's lactate vehicle was independently associated with reduced glomerular filtration rate in a retrospective study of 238 consecutive coronary artery bypass graft patients [51]. The safety of either solution for fluid management in sepsis would need to be demonstrated in clinical trials. 


\section{Conclusion}

Compelling evidence is now at hand indicating that HES infusion places sepsis patients at increased risk for ARF. New data also suggest the possibility of poorer survival among sepsis patients receiving HES, especially higher doses. Clearly, HES 200/0.5 and HES 200/0.62 cannot now be recommended in sepsis. The effectiveness and safety of other HES solutions in this indication remain to be determined in future clinical trials.

\section{List of abbreviations}

ARDS: Adult respiratory distress syndrome; ARF: Acute renal failure; HES: Hydroxyethyl starch; IQR: Interquartile range; $\mathrm{pH}_{\mathrm{i}}$ : Gastric intramucosal $\mathrm{pH}$; RES: Reticuloendothelial system; RRT: Renal replacement therapy; SIRS: Systemic inflammatory response syndrome.

\section{Competing interests}

The author(s) declare that they have no competing interests.

\section{Authors' contributions}

CJW is sole author.

\section{References}

I. Gong MN, Thompson BT, Williams P, Pothier L, Boyce PD, Christiani $D C$ : Clinical predictors of and mortality in acute respiratory distress syndrome: potential role of red cell transfusion. Crit Care Med 2005, 33: I 191-1198.

2. Pittet D, Thievent B, Wenzel RP, Li N, Auckenthaler R, Suter PM: Bedside prediction of mortality from bacteremic sepsis. A dynamic analysis of ICU patients. Am J Respir Crit Care Med I996, I 53:684-693.

3. Weycker D, Akhras KS, Edelsberg J, Angus DC, Oster G: Longterm mortality and medical care charges in patients with severe sepsis. Crit Care Med 2003, 31:2316-2323.

4. Yu DT, Platt R, Lanken PN, Black E, Sands KE, Schwartz JS, Hibberd PL, Graman PS, Kahn KL, Snydman DR, Parsonnet J, Moore R, Bates DW: Relationship of pulmonary artery catheter use to mortality and resource utilization in patients with severe sepsis. Crit Care Med 2003, 3 I:2734-274I.

5. Braun L, Riedel AA, Cooper LM: Severe sepsis in managed care: analysis of incidence, one-year mortality, and associated costs of care. J Manag Care Pharm 2004, 10:52 I-530.

6. van Biesen W, Yegenaga I, Vanholder R, Verbeke F, Hoste E, Colardyn $\mathrm{F}$, Lameire N: Relationship between fluid status and its management on acute renal failure (ARF) in intensive care unit (ICU) patients with sepsis: a prospective analysis. J Nephrol 2005, I 8:54-60.

7. Rackow EC, Mecher C, Astiz ME, Griffel M, Falk JL, Weil MH: Effects of pentastarch and albumin infusion on cardiorespiratory function and coagulation in patients with severe sepsis and systemic hypoperfusion. Crit Care Med 1989, I7:394-398.

8. Brun-Buisson C, Doyon F, Carlet J, Dellamonica P, Gouin F, Lepoutre A, Mercier JC, Offenstadt G, Régnier B: Incidence, risk factors, and outcome of severe sepsis and septic shock in adults. $A$ multicenter prospective study in intensive care units. French ICU Group for Severe Sepsis. JAMA 1995, 274:968-974.

9. Falk JL, Rackow EC, Astiz ME, Weil MH: Effects of hetastarch and albumin on coagulation in patients with septic shock. J Clin Pharmacol 1988, 28:412-4I5.

10. Groeneveld AB, Bronsveld W, Thijs LG: Hemodynamic determinants of mortality in human septic shock. Surgery 1986 99:140-153.

II. Marik PE, Iglesias J: Would the colloid detractors please sit down! Crit Care Med 2000, 28:2652-2654
12. Mangialardi RJ, Martin GS, Bernard GR, Wheeler AP, Christman BW Dupont WD, Higgins SB, Swindell BB: Hypoproteinemia predicts acute respiratory distress syndrome development, weight gain, and death in patients with sepsis. Ibuprofen in Sepsis Study Group. Crit Care Med 2000, 28:3 I37-3। 45.

13. Schortgen F, Deye N, Brochard L: Preferred plasma volume expanders for critically ill patients: results of an international survey. Intensive Care Med 2004, 30:2222-2229.

14. Treib J, Haass A, Pindur G, Seyfert UT, Treib W, Grauer MT, Jung F, Wenzel E, Schimrigk K: HES 200/0.5 is not HES 200/0.5. Influence of the C2/C6 hydroxyethylation ratio of hydroxyethyl starch (HES) on hemorheology, coagulation and elimination kinetics. Thromb Haemost 1995, 74: | 452 - 1456

15. Vincent JL: Fluid management: the pharmacoeconomic dimension. Crit Care 2000, 4(Suppl 2):S33-35.

16. Wiedermann CJ: Hydroxyethyl starch-can the safety problems be ignored? Wien Klin Wochenschr 2004, I I 6:583-594.

17. Boldt J, Heesen M, Welters I, Padberg W, Martin K, Hempelmann G: Does the type of volume therapy influence endothelialrelated coagulation in the critically ill? $\mathrm{Br}$ J Anaesth 1995 , 75:740-746.

18. Boldt J, Müller M, Heesen M, Heyn O, Hempelmann G: Influence of different volume therapies on platelet function in the critically ill. Intensive Care Med 1996, 22:1075-I08I.

19. Boldt J, Heesen M, Müller M, Pabsdorf M, Hempelmann G: The effects of albumin versus hydroxyethyl starch solution on cardiorespiratory and circulatory variables in critically ill patients. Anesth Analg 1996, 83:254-26I.

20. Boldt J, Müller M, Heesen M, Neumann K, Hempelmann GG: Influence of different volume therapies and pentoxifylline infusion on circulating soluble adhesion molecules in critically ill patients. Crit Care Med 1996, 24:385-39I.

21. Boldt J, Mueller M, Menges T, Papsdorf M, Hempelmann G: Influence of different volume therapy regimens on regulators of the circulation in the critically ill. BrJ Anaesth 1996, 77:480-487.

22. Boldt J, Müller M, Mentges D, Papsdorf M, Hempelmann G: Volume therapy in the critically ill: is there a difference? Intensive Care Med 1998, 24:28-36.

23. Asfar P, Kerkeni N, Labadie F, Gouëllo JP, Brenet O, Alquier P: Assessment of hemodynamic and gastric mucosal acidosis with modified fluid versus $6 \%$ hydroxyethyl starch: a prospective, randomized study. Intensive Care Med 2000, 26: I 282-I 287.

24. Schortgen F, Lacherade JC, Bruneel F, Cattaneo I, Hemery F, Lemaire $F$, Brochard L: Effects of hydroxyethylstarch and gelatin on renal function in severe sepsis: a multicentre randomised study. Lancet 200I, 357:911-916.

25. Molnár Z, Mikor A, Leiner T, Szakmány T: Fluid resuscitation with colloids of different molecular weight in septic shock. Intensive Care Med 2004, 30: I356-1360.

26. Palumbo D, Servillo G, D'Amato L, Volpe ML, Capogrosso G, De Robertis $E$, Piazza $O$, Tufano R: The effects of hydroxyethyl starch solution in critically ill patients. Minerva Anestesiol 2006, 72:655-664.

27. Brunkhorst FM, Engel C, Bloos F, Meier-Hellmann A, Ragaller M, Weiler N, Moerer O, Gruendling M, Oppert M, Grond S, Olthoff D, Jaschinski U, John S, Rossaint R, Welte T, Schaefer M, Kern P, Kuhnt E, Kiehntopf M, Hartog C, Natanson C, Loeffler M, Reinhart K: Intensive insulin therapy and pentastarch resuscitation in severe sepsis. The German Competence Network Sepsis (SepNet). N Engl J Med 2008, 358: I 25-139.

28. Haupt MT, Rackow EC: Colloid osmotic pressure and fluid resuscitation with hetastarch, albumin, and saline solutions. Crit Care Med 1982, 10:159-162.

29. Rackow EC, Falk JL, Fein IA, Siegel JS, Packman MI, Haupt MT, Kaufman BS, Putnam D: Fluid resuscitation in circulatory shock: a comparison of the cardiorespiratory effects of albumin, hetastarch, and saline solutions in patients with hypovolemic and septic shock. Crit Care Med 1983, I I:839-850.

30. Veneman TF, Oude Nijhuis J, Woittiez AJ: Human albumin and starch administration in critically ill patients: a prospective randomized clinical trial. Wien Klin Wochenschr 2004, I 1 6:305-309.

3I. Boldt J, Knothe C, Schindler E, Hammermann H, Dapper F, Hempelmann G: Volume replacement with hydroxyethyl starch solution in children. Br J Anaesth 1993, 70:661-665. 
32. Kumle B, Boldt J, Piper S, Schmidt C, Suttner S, Salopek S: The influence of different intravascular volume replacement regimens on renal function in the elderly. Anesth Analg 1999, 89: I I 24-II 30.

33. Cittanova ML, Leblanc I, Legendre C, Mouquet C, Riou B, Coriat P: Effect of hydroxyethylstarch in brain-dead kidney donors on renal function in kidney-transplant recipients. Lancet 1996, 348: $1620-1622$.

34. SAFE Study Investigators: A comparison of albumin and saline for fluid resuscitation in the intensive care unit. $N$ Engl J Med 2004, 350:2247-2256

35. Castro V], Astiz ME, Rackow EC: Effect of crystalloid and colloid solutions on blood rheology in sepsis. Shock 1997, 8:104-107.

36. Paes-da-Silva F, Gonzalez AP, Tibiriçá E: Effects of fluid resuscitation on mesenteric microvascular blood flow and lymphatic activity after severe hemorrhagic shock in rats. Shock 2003, 1 9:55-60.

37. Schildt $B$, Bouveng $R$, Sollenberg M: Plasma substitute induced impairment of the reticuloendothelial system function. Acta Chir Scand 1975, I41:7-13.

38. Thompson WL, Fukushima T, Rutherford RB, Walton RP: Intravascular persistence, tissue storage, and excretion of hydroxyethyl starch. Surg Gynecol Obstet 1970, I 3 I:965-972.

39. Pfeifer U, Kult J, Forster H: Ascites als Komplikation hepatischer Speicherung von Hydroxyethylstärke (HES) bei Langzeitdialyse. Klin Wochenschr 1984, 62:862-866.

40. Dienes HP, Gerharz CD, Wagner R, Weber M, John HD: Accumulation of hydroxyethyl starch (HES) in the liver of patients with renal failure and portal hypertension. I Hepatol 1986, 3:223-227.

4I. Jurecka W, Szepfalusi Z, Parth E, Schimetta W, Gebhart W, Scheiner $O$, Kraft D: Hydroxyethylstarch deposits in human skin - a model for pruritus? Arch Dermatol Res 1993, 285:13-19.

42. Auwerda J. Wilson JH, Sonneveld P: Foamy macrophage syndrome due to hydroxyethyl starch replacement: a severe side effect in plasmapheresis. Ann Intern Med 2002, 137:1013-1014.

43. Lukasewitz P, Kroh U, Löwenstein O, Krämer M, Lennartz H: Quantitative Untersuchungen zur Gewebsspeicherung von mittelmolekularer Hydroxyethylstärke 200/0,5 bei Patienten mit Multiorganversagen. J Anaesth Intensivbeh 1998, 3:42-46.

44. van Rijen EA, Ward J, Little RA: Effects of colloidal resuscitation fluids on reticuloendothelial function and resistance to infection after hemorrhage. Clin Diagn Lab Immunol I998, 5:543-549.

45. Shatney $\mathrm{CH}$, Chaudry $\mathrm{IH}$ : Hydroxyethylstarch administration does not depress reticuloendothelial function or increase mortality from sepsis. Circ Shock 1984, I 3:2 I-26.

46. Barron ME, Wilkes MM, Navickis RJ: A systematic review of the comparative safety of colloids. Arch Surg 2004, I39:552-563.

47. Bork K: Pruritus precipitated by hydroxyethyl starch: a review. $\mathrm{Br}$ J Dermatol 2005, I 52:3-12.

48. Davidson IJ: Renal impact of fluid management with colloids: a comparative review. Eur J Anaesthesiol 2006, 23:721-738.

49. Wiedermann C): Renal failure in septic patients receiving hydroxyethyl starch. Minerva Anestesiol 2007, 73:44I.

50. Boldt J, Brenner T, Lehmann A, Lang J Kumle B, Werling C: Influence of two different volume replacement regimens on renal function in elderly patients undergoing cardiac surgery: comparison of a new starch preparation with gelatin. Intensive Care Med 2003, 29:763-769.

51. Winkelmayer WC, Glynn RJ, Levin R, Avorn J: Hydroxyethyl starch and change in renal function in patients undergoing coronary artery bypass graft surgery. Kidney Int 2003 , 64:1046-1049.

\section{Pre-publication history}

The pre-publication history for this paper can be accessed here:

http://www.biomedcentral.com/1471-227X/8/1/prepub
Publish with Biomed Central and every scientist can read your work free of charge

"BioMed Central will be the most significant development for disseminating the results of biomedical research in our lifetime. "

Sir Paul Nurse, Cancer Research UK

Your research papers will be:

- available free of charge to the entire biomedical community

- peer reviewed and published immediately upon acceptance

- cited in PubMed and archived on PubMed Central

- yours - you keep the copyright

Submit your manuscript here:

http://www.biomedcentral.com/info/publishing_adv.asp
BioMedcentral 